\title{
Immigrants and Refugees in Globalized World
}

ISSN: 2311-8636 (Print)

ISSN: 2312-2021 (Online)

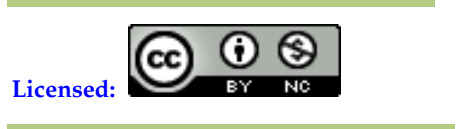

Source of Support: Nil

No Conflict of Interest: Declared

*Email for correspondence:

anandamajumdar2004@yahoo.co.uk

\section{Ananda Majumdar}

Researcher, University of Alberta, Harvard Graduate School of Education (Professional Education), Antarctic Institute of Canada, CANADA

business exchanges and is useful for all developing countries on the globe, if those are its advantages, people migration through illegally is its disadvantages, there was no global terms of legal or illegal immigration at the beginning of $19^{\text {th }}$ century, United Nations General Assembly in 1948 states that everyone has the right to leave any country including his own and to that return country, but it has not been honoured by developing countries, due to changes of world order, population growth, regional conflicts, war, civil war, poverty, people start to moving from one to another country, population growth in developing countries is one of the most important reasons that forced people leave their land and to migrate illegally or legally, though legal immigration has processes for their further innovation, development but illegal immigration is a curse for developed countries, countries that are industrially developed like United Arab Emirates, Kuwait, people from developing world are forcing to leave due to war, civil war, community clashes, and to taking shelter as a refugees but at the end most of them are not returning after normalization of their own conflicts, people are moving without documents, in the United Europe, European Union policies are trying to control immigration from nonmember countries such as immigrants from Morocco and other North Africans countries are migrating illegally to Spain for a better life and to came out from miserable life from their own countries but the Spain Government declares to deport people from nonmembers countries who are living illegally in Spanish land, England declares to controlling access of all Romanian and Bulgarian to the UK who are benefitting as EU member country, upon acceptance of all East European countries as the member of EU, approximately 427,000 East Europeans, mostly from Poland have registered for employment in Britain, though Western Europe are more inclined to hire Eastern European than Asian and Africans, but yet Britain decided to came out from EU because of illegal immigration to Britain from Eastern Europe which negatively affected their economy and job security of original British citizens', so what is the solution for the worst crisis of illegal immigration and refugees accommodation world-wide? Is it forcing them to back their own countries? Is it taking initiatives through both North and South countries for the solution of the problem? Or is it solving really? A continual discussion of 
alternative solutions world-wide has to be discovered for the reduction of the problem of refugees and immigration world-wide, communication between developing and the developed countries have to be strength for the resolution of faster population growth in developing countries, assistance by the developed countries in war conflicted regions has to be increased, universal birth control education need to be formed, I tried to discussed the problems, reasons, and its solution as one of my focused areas in international development, it is something that I would like pursue my study in the near future as a continuing student, I hope I will be succeed.

Keywords: Globalization, Nation-state, UNCHR, Third Country Rule by Germany, Mobilization, Undocumented Aliens, Refugees, Economic Immigrants

\section{INTRODUCTION}

Moving around the world is not a new thing, intellectuals visited various countries in the world for invention and explore for the betterment of human being, dates, periods, and decades changes people are moving around the world now a days for better living standard, better opportunities, for survival, from their countries where poverty grabbed the entire society, until the independence of the United States of America there was no such a world legal or illegal immigration, people from Africa came to the States and became enslaved, European came to the States for settlement, after independence in $17^{\text {th }}$ century US made constitution for their land and the term immigration, immigrant discovered, immigrant from Northern and Southern Europe and then from China were the earlier immigrants to the United States, there was law for immigrants in the early but was not restricted, as a result immigration from China increased for the building of the railroads, goldmine etc. in the West Coast, however it was the starting of problems blaming by the White Americans to those Chinese immigrants for lower wages and various economic problems, as a result Radical Exclusion Act. Banned immigration from China except students and diplomats, because of various problems comes out Asiatic Barred Zone Act. Banned immigration from Asia and then there was several act. Such as 1924 Immigration Act. which banned people to be naturalized US citizen except White people who are naturalized by their origin, in 1965 US visa and immigration brought a quota system for immigration from around the world and it was 7 percent for each nation for visa allowance, as a result Mexico got restriction instead moving to the US freely, US and other developed countries immigration laws has been tightened day by day because of the changes of immigration nature, to stop illegal immigration, false refugee applications but the problem of undocumented immigration, false refugee applications have not ended and it is a prediction that I will increase instead decrease if further initiatives are not taken.

\section{Methodology}

I go through various e-websites, e-letter, newspaper, and book, I collected information about the areas, made various drafts and make the final drafts after understanding of the entire topic, I then wrote by my own words and understanding by using information that I collected at the beginning

\section{REsult ANd Discussion}

Globalization helps people to move around the world due to free nations, trade, economy, and border. There is an estimated 200 million immigrants world-wide, among them 115 
million people live in developed countries, approximately 38 million people (20\%) lives in the United States of America alone which makes 13\% of its total population, 33\% lives in Europe, 75\% lives in other countries such as NZ. AUS, Canada etc. between 1990 to 2005 there were approximately 36 million people world-wide as immigrant, approximately 33 million were in developed countries (G7, Australia, New Zealand, Luxemburg, all Scandinavian countries, South Africa and so on), 75\% increases in 17 countries and in the same period immigrant decreases in 72 countries, it is a big mobilization world-wide through open border, various exchanges, agreements between countries, students, refugees and through many processes. It is a problem, an advantage but immigration mostly due to force, due to conflict, due to environmental disruption especially from coastal countries, from developing countries to developed countries, poor developing countries to rich developing countries, it is for better life, better living standard, however it has courage as well even to know problem of loneliness, different culture and norms and less income then the original inhabitants, according to the European Union, vast amount of people are immigrating to other countries because of current form of globalization, they are either forcing to leave from their own country due to devastated condition such as Syria, Lebanon, North Korea, Former Soviet States, and all most all African, Middle East countries for living a life, as I say it has advantage in the sense that those people in industrialize countries are working in the field which is not that popular job code to the original inhabitants of western countries, they do their job for a longer period and thorough the acceptance of lower salaries, they are the source of host countries diversity, talent pool through their higher education of their original countries and it's modification through the host countries educational institutes, sometime educational assessment by the government authority such as Government of Alberta's IQUAS(International Qualification Assessment Service), however it has problem as well in the sense that immigrant can be exploited for their cheap labour, immigration is a brain drain for their original country(India is suffering through people movement to other countries as a result development is not getting fast due to the lack of skilled labour, academician), new comer can be the source of crime through various forms of crime, drug trafficking, corruption due to facing various social-economical problem in their migrant countries, after all honeymoon period cannot be longer and soon they realize the real life and problems, it is a real fact that due to the lack of education, differences of educational curriculum, cultural differences they face problem in their migrant country as well, so problem is always their companion everywhere if they cannot adjust in a new society, community, they soon recognize as social-political problem in the name of racism which is innate, they are the problem to the local poor inhabitants in the sense that immigrants and refugees appear to get more benefits than them, the problem of illegal immigration is a burning issue in all developed countries which spill over to ill-feelings among the immigrants who are lawabiding and contributing to the economy, there is no way that illegal immigrants can be compared with legal international students, who are contributing to the nation their best through various sources such as financial investment in education, voluntary work in the community, raises awareness of social-economic problem and thus trying to turn to be a model citizen of the society of the migrant country, I am an example, there is no permanent place for illegal immigrants because of their illegal status and they flee anywhere anytime and this can often make sensational headlines that immigration is mostly illegal and out of control and sometime it brings negative effect among legal immigrant communities, can I ignore incidents that is happening on US legal immigrant communities at present through the killing of Indian students, engineers who are the bright future of the US generation but why then it is happening? Is it not a negative effect 
of thinking about illegal migration, about those people who came to the States illegally and moving here and there due to nervousness and thus combined every immigrant on a same point? US economic boom in 90's designed to bring immigrants from around the world who can contribute to the country's economic, social, cultural point of view but were they able to represent those immigrant societies? I would say it was an improper representation as a biased, stereotyped community such as South Asian Americans are inadvertently looked upon negatively by many in the Black and Latino communities, and so on, unfairly blaming on immigrants for their economic problems etc. In the United Kingdom policies and plans are affecting on immigration, immigration officers are getting more power then before to detain and increase the number of asylum seekers whose appeals have been refused, policies creates a long term process for the asylum centres house people who may be waiting up to seven years before the hearing of their case decision whether they will be granted or deport (Amnesty International), thus immigration issues brings a hype to the UK people as well, approximately $73 \%$ of the original inhabitants thinks too many immigrants in the UK, 75\% thinks immigrants put a strain on public services, $39 \%$ thinks immigrants bring disease to the UK and the least percentage of the British thinks immigrants are the symbol of multiculturalism. In the United Europe, European Union policies are trying to control immigration from nonmember countries such as immigrants from Morocco and other North Africans countries are migrating illegally to Spain for a better life and to came out from miserable life from their own countries but the Spain Government declares to deport people from nonmembers countries who are living illegally in Spanish land, England declares to controlling access of all Romanian and Bulgarian to the UK who are benefitting as EU member country, upon acceptance of all East European countries as the member of EU, approximately 427,000 East Europeans, mostly from Poland have registered for employment in Britain, though Western Europe are more inclined to hire Eastern European than Asian and Africans, but yet Britain decided to came out from EU because of illegal immigration to Britain from Eastern Europe which negatively affected their economy and job security of original British citizens, problems are bigger than advantage for those immigrants, they have been harassed racially, gets various notice, jokes on their small business but yet they control over it and become successful businessman in Britain(Indian, Pakistani and Polish), In Indonesia Chinese immigrants were affected by the original inhabitants due to financial crisis at the end of 1990, anti-immigrant violence has observed in South Africa in 2008 by the poor South Africans who becomes hostile on immigrants from other parts of African countries, killing some 50 immigrants and forces thousands to leave South Africa, South Africa Cricket Team was white people oriented but it changes now and it is due to national sentiment of the African region, it is same in Zimbabwe, where the cruel president Mugabe forced to white people to leave Zimbabwe and forced to leave Zimbabwean national cricket team(Andy Flower and Grant Flower are two brothers and were the brightest cricketer of Zimbabwe national cricket team, they leave Zimbabwe and now are living in Britain due to political turmoil by the cruel Mugabe government against the white people, so these are example of anti-immigrant sentiment and it has also observed that the sentiment arises when economic hardship creates in every country because it is easy to target minorities, immigrants in every countries for blame. So, from America to Europe, Asia to Africa every continent have anti-immigrant sentiment within their original citizens somewhere is soft in the name of sophisticated discrimination and somewhere is real hard in the name of open violence on those immigrants, and sometime there is no definition of illegal or legal immigrants, they all are under same point as I mention before, the government of developed countries are getting 
huge pressure from public to restrict the border through enforcement and security, to be strict on immigration policies it is a misunderstanding within immigrants that if they have no job in industrialised country, government will pay them for their livelihood, it is a welfare system of developed countries and has time limitation but do you think local citizens will take it easily? I do not think so, maybe they will not protest as a civil citizen but when economic turmoil will create they will somehow protest against of all government assistant systems which favours immigrants. Government of Canada has one year financial assistant program to all legal new comer to Canada from world wide, though I did not take any assistants because of my own qualities from the beginning of an international student and then a permanent resident of Canada through my Canadian qualifications and through several processes, but others are not like me and I will not also compare myself with other immigrants who are always waiting for government assistant and doing nothing by their own efforts, it may be their lack of educational qualities or may be their laziness or may be their concern about the advantage as a new comer facility program, is focused by the government as a system of welfare country, God knows. The percentage of the immigrants grows up to estimated 3.1\% from $2.9 \%$ in 1990 and no body knows about the actual percentage of illegal immigrants, however a rough estimation has been provided by the International Organization for Migration in Geneva which is approximately $15 \%$ to $20 \%$ of entire immigration population world wide due to the outcome of globalization, I said during emergency such as economic turmoil, or some other social crisis, legal and illegal immigrants both were in the same point for the blame due to anti-immigrant sentiment and I also prove evidence but I will also say that during normal time legal immigrants basically does not face problems, they have credit for their economic contribution, making a country more diverse through their cultural participation, political participation and through the participation of many areas, Canada is a great example, many Canadian Ministers are Indian origin, a country which has been a destination for international immigrants throughout its history, Government of Canada's immigration is governed by the Immigration and Refugee protection Act of 2002 and its regulations, and has been clearly divided by its social, economic, cultural goal through the economic immigration program(legal immigrants) and the humanitarian goals of refugee protection program(illegal immigrants appeals and applies to be recognised as refugee lawfully and shows required documents which is true and is not true as well), Canada has accepted between 175000 and 250000 per year including between 22000 to 30000 refugees, in 200532 percent of the refugees came from Africa and the Middle east, 33.1\% came from Asia and Pacific, 21.3\% came from South America and Central America and 11.2\% refugee came from Europe(Citizenship and Immigration Canada, 2006), refugees from coastal countries are recognised as environmental refugee(El-Hinnawi 1985), it has been indicated that due to climate change world wide, estimate environmental refugee would be 150 million in 2050 with approximately 100 million being from low-lying coastal area, 50 million from agriculturally dislocated areas, approximately 1 million from islands states (Myers and Kent 1995), most of the people displaced by the environmental change expected to be in Asia and Africa( Maldives, Fiji , Caribbean countries, Sri Lanka, etc.) and hence likely to migrate to Canada, Canada will face Mexican environmental refugee as well. In Canada 59,999 permanent residents were admitted through federal economic skilled category, is called skilled worker class directly through the Citizenship and Immigration Canada, those skilled workers are from managerial, professional or highskilled occupations(FSW), from trade skilled level(FST) and from Canadian Experience Class(CEC), 39, 749 were under FSW, 2,428 were under FST program and 17,822 were from CEC immigration program, they were all successful immigrants to Canada from all 
over the world, Canada has some other ways for permanent immigration such as care giver program through caring children, caring people with high medical need and the legacy care-giver program, in 2016 the number of successful immigrant through caregiver program was 18,467, a total of 867 successful admissions were from business class immigrants and one of the most lucrative way is Provincial Nominee Program(PNP) through the nomination of every provinces of Canada and it was 46,170 successful immigrants through provinces of Canada from provincial international students, skilled worker, etc. I was nominated by the honorable Government of Alberta, Canada under Post Graduate stream category provincial nominee program, I received my approval nomination within 15 days after application and then I applied for the federal permanent resident application and I finally received my PR status within a year, it was smooth and clear as a provincial nominee, Canada also accepts family members of its permanent residents and citizens under family class category, so that Canadian citizen or permanent resident can sponsor their family members(father, mother, siblings, cousins, adopted children) from outside Canada, total family class immigrants were 78,004 in 2016, Canada is one of the most humanitarian country in the world and it has immigration process under Protected Persons, Refugees and Humanitarian category as well, in 2016 a total of 62,348 people were admitted to Canada under this category through asylum system, resettled refugees, or people admitted for humanitarian and compassionate considerations and under public policies, in 2016 a total of 46,319 refugees were resettled to Canada which was exceeding the high end of the planned admission range of 46,000, most of them are from Syria and the rest of the world by the federal government's direct re-settlement program, in 2016 the majority of the resettled refugees totalling 27,957 were directly supports by the government, among them 23,523 resettled as government assisted refugees, 4,434 resettled as blended visa-office referred refugees and 18,362 were privately sponsored refugees, under refugee settlement process, 12,116 asylum claimants and their dependents received permanent resident of Canada under the Protected Persons in Canada. IRPA authorises the Minister of Immigration and Refugees and Citizenship to consider the situation of and grant permanent resident status to, individuals and their families who would not otherwise qualify under an immigration program and this one of Canada's most humanitarian point for compassionate consideration or for reasons of public policy, provide the flexibility to approve deserving cases to come forward, countries like India, Philippines, China, Syria, Pakistan, USA, Iran, France, UK and Eritrea are top ten sources countries to immigrate to Canada in 2016, estimated Canadian immigration plan for the year of 2018, 2019, 2020 are 310,000, 330,000, 340,000. Temporary migration to Canada as a students, workers are also a sign to be settled as a permanent resident of Canada in the future, Canada is an attractive destination for international students from around the world and in the top ten global international study destination, those international students have great contributions to Canada through their studies, investments, cultural, and social collaboration, and adopt Canadian social system easily through their advanced transition, in 2016 Canada admitted 8,246 individuals who previously studied as an international student, there are other sources for temporary entry to Canada such as visitor, temporary residents permit etc., In the United States legal immigrants from Japan, Korea, India, Bangladesh, approximately 600,000 Asian immigrants make the US their home, US computer hub Silicon Valley is the second home for Indians, Chinese origin immigrants, Orange Country of California is the hub of Asian immigrants, they make those places of the US a diverse place through their investment and to making restaurants, shopping mall, transforming a sleepy community into a bustling commercial centre etc. I would say globalization is for legal immigrants and it can 
not be for illegal immigrants, therefore for the normalization of anti-immigrant sentiments through which legal immigrants also faces problem due to illegal immigrant's issues, must be stopped by the government of any country which can be a positive aspect for a country, for a society and good for legal immigrants in all weather. Migrants and refugee problems are growing through its rising waves every year due to poverty, political violence, natural disaster, civil war and for many reasons, over 65 million people displaced abroad according to the United Nations Commission on Human Rights (UNHCR), world is facing challenges due to increases of migration, 24 people per minute, per day forced to flee from their land, their home country in 2015, about 1 out of 113 people were either asylum seeker, refugee and half of the refugee population was under 18, two third of the displaced population were remain within the border of their countries and by the end of 2016 a total of estimated 40.3 million were refugees world wide, Syrian civil war for 7 years turned half of the countries population refugee(a total of 21 million) and estimated 6 million refugees are in Jordan, Turkey, Lebanon, and rest of them are in Europe to showing regional crisis, it is hard for them to live a inhuman life in those countries, they are exploiting in the labour market of Jordan, Turkey, Lebanon, are forcing to do any kind of job for a minimal livelihood, due to administrative and bureaucratic difficulties NGO's are facing problem to help those Syrian refugees, Syria is the focal point of refugee crisis at this moment but there are other areas in the world that, displaced people are crossing Mediterranean sea from Libya to Italy, Rohingya Muslims in Myanmar are forcing to leave their home from Myanmar and they are taking shelter as a refugee to India and Bangladesh, thousands of Dominicans are stateless in Caribbean, Afghanistan is another focal point of refugee in the world after Syria are forcing to flee from their country due to war everywhere in the country, in 1980 Pakistan hosted estimated 4 million Afghan refugee who left their home to escape against the war of Soviet Union, later most of those afghan refugees permanently stayed in Pakistan and Iran and few of them returned to Afghanistan and were killed as well by Afghan Taliban group, approximately 60 percent of the world's 22 million refugees and the 80 percent of internally displaced refugees are living in the cities than in camps, due to the lack of housing, healthcare, education, skills training and social services those cities are facing huge problems, as a result displacement increases, violence increases between refugees and the local citizens, as suggestion by various scholars thinks that UNHCR should encourage UN member states to engage in positive and meaningful collaboration with municipal authorities by facilitating the flow of technical experts and resources and thus help those cities for the help of refugee problems, I already mention about Canada's role as one of the biggest humanitarian country to provide shelter with future refugee re-settlement plan as well. The problem is mostly due to economic and security reasons, after the World War 2 the largest refugee movement was in between India and Pakistan, estimated 14 million people crossed the newly created border in Indian subcontinent, approximately 8 million Muslims left India for Pakistan and 6 million Hindus and Sikhs moved to India from Pakistan because of religious entity (Divide and Rule policy on the basis of Hindu and Muslim religion), the importance of the problem has been valued by the UN to declaring World Migration day on December 4 every year, summit like UN Summit for Refugees and Migrants, Former US President Barak Obamas' Leaders' Summit puts a global spotlight on the issue and to take effective measures to a growing humanitarian crisis, it has observed that in New York half of the business owners are from other countries immigrated to the US, in London estimated 3 millions citizens born in other countries, that healthy picture of diversity in London and New York are bright example of immigrants global city and it is also interesting that Mr. Khan has been chosen as the Mayor of London, UK, those initiatives 
are measures to bring harmony among immigrants and the inhabitants of countries like UK and USA and to give positive and meaningful response to the context of this humanitarian problem, several cities in the world launches to better integrate new comers, New York has begun an identification program which helps to bring the sense of belongingness among the immigrants, in 2015 London borough provided support to more than a thousands unaccompanied and asylum seeking children, Paris opened a refugee centre in the heart of city, initiatives like that are examples to bring positive and meaningful solution of refugee problem, though it is hard but initiatives for human kind and the harmony among societies, communities and countries. The United States provided shelter estimated 8,60000 refugees from around the world after $9 / 11$ and about 59 percent Americans helps for the re-settlement and for the assistance of refugees in their country, The US President Donald Trump brought few rules and regulations to ban on immigration and refugee but reality said another story, it did not stop and it cannot because of US attraction and its popularity world-wide, but USA also is facing the problem of illegal immigration due to the present concept of globalization, which is making migration and terrorism much easier, The United States of America and Canada are recognized as a nation of immigrants but the problem of terrorism increases due to illegal immigration in those countries as well as a big social problem, terrorism is not new in the world as it is a part of all mot all developing countries social system but it is a new concept in North America especially in the USA and Canada, the fact the people of the US and Canada are not that aware of the consequences of this problem because of their well living standard but liberal immigration process somehow brings trouble in the lifestyle of the people of those developed countries, more than 10 million undocumented people are residing in the USA and is growing by 700000 every year, or 3 out of 100 people in the USA are undocumented, illegal immigration is a big threat and curse for the US society because of its negative effects on border security, social security, encouragement the culture of illegality, helping terrorists, helping underground antisocial activities, drug traffickers, even though it is not a direct threat, so if diversity and economic contribution are positive side, these are negative side and the percentage of the negative side is much bigger than positive sides, however something needs to be done for the reduction of anti-social elements and to recognizes the identification of illegal individual who are called guests worker as well, these initiatives will help US to re-cover situations from illegality, and to help illegal people to be legal and thus amalgamation with the main stream of US society and the people, all guest workers must be identified through biometrically nation-wide such as fingers print, retina scanning etc. US Homeland Security has a program called basic pilot employment verification program which is for the discouragement of undocumented work arrangement between employers and employee and/or from various sources, worker visit program through which employers will help their hiring guest worker for their electronic registration and to confirm their eligibility to work in the United States, guest worker program is not that attractive for the guest worker because of their status with the main worker stream, therefore an incentives program should be added for those workers for their compliances or obey to the law, however make sure that the guest workers incentive program is not connected to the way of granting or getting US citizenship or to get US social benefit program then it will be worsen, illegal guest workers should left from US and re-enter legally through the checkpoint as one of the compliance of the law and give few days to the immigration or border security officers for biometric identification and thus to recognizes terrorists and anti-social people, possibilities of reentry program will bring encourage to those illegal workers or individuals as a chance to be legal for a normal life in the USA, making sure there must not be any bureaucratic way 
with guest workers program for the connection of green card program because guest workers program is an opportunity for those illegal individuals to be legal but not a green card holder or a way to be green card holder, so part of the government officials need to be very clear about the program and no misuse through bureaucratic way, then all legal guest workers should find their sponsor employers, thus they continue their living and work even changing or ending of their sponsorship and find another sponsors, thus a legality will create in the United States and the respect of American law and traditions as well, if they are not obeying then lifetime banning to get US Citizenship or banning to qualify guest worker program need to be added, however those are initiatives that is depending on US parliament that how does rulers adapt those program for the betterment of USA and for legal migration from illegality. In 2017 there was various migration issues raised world-wide such as, the President of the United States Donald Trump Administration took steps to reducing migrants entering to the US from the world even legally as one of the solution steps to escape the States, more than 6,30000 Rohingya refugees crossed into Bangladesh from Myanmar(they had been forced by the military of Myanmar) described by the UN as the fastest fastest growing refugee crisis and an example of ethnic cleansing, European leaders pursued a collaboration with North African countries like Libya to provide support to cracking down illegal migration through the crossing of Mediterranean sea and to reduce life loss as well into the sea, Germany did an agreement with Egypt and Tunisia for the cracking down of illegal immigrants and smugglers as well, millions of refugees were unable to return their home countries, Rohingya refugees flee to Bangladesh(624000 estimated), people of South Sudan turned into refugee due to the internal problem of Sudan and moved other countries(6,68000 estimated), Uganda and Turkey were accepting and accommodating refugees from neighbouring and from other parts of the worlds, while Jordan and Lebanon were pressuring refugees to leave their country, President of the United States Donald Trump Administration reduced the 2018 refugee re-settlement program and as a result global refugee re-settlement program was dropped, The Dominican Republic pushed out estimated 70,000 Haitians and estimated 5,00000 Afghans left Iran and Pakistan, returning of refugees from those countries, pushback as a step from the government was due to their own rising problems and inabilities of long term accommodation, food, sanitation, increasing anti-social elements, smuggling, drug trafficking, human assault, women rights concerns etc. , nativist movement was growing in Europe and America for their citizens security and to pushback refugees, illegal immigrants from America and Europe, it was a pressure from them to the ruling government to take actions against refugees, illegal immigrants and thus nationalism rises up, in South America Peru, Columbia and Brazilian government worked much as a record for the asylum application of Venezuelan refugees and welcomed in their countries, Chile and Argentina took restrictive policy to escape their country from the illegal immigration of Haitians people. If we look back to Europe we can study that Europe from the beginning has been shaped by migration through merchants, craftsman, intellectuals individuals and on the other way people from Europe was migrated to their colonial countries, Americas and the Antipodes, they have history of forced migration because of many wars between Russians and Austro-Hungarians and Ottoman empires, recently migration in Europe has been increased from 3 percent to 6 percent (1960-1973). The UK, France and Germany are the prime location for migration and be their citizen, it was due to labour needs but the oil crisis in 1973 changes everything and dropped migration in western European countries, people from world-wide are coming to Western Europe through family class immigration, work permits for the attraction of those countries even today, EU member countries also issued millions of work permits to allow 
foreign individuals to enter, in 1997 Britain's half of the estimated 54,000 permit's went to Americans and Japanese mainly for highly skilled jobs, while EU permits went to seasonal farm workers, in Germany, Belgium, Austria foreign born residents remain low estimated 9 percent, where in Spain it is under 2 percent, in 1984 there were 1,04,000 asylum application in Western Europe and grew up estimated 692,000 in 1992, in 1990 it was declined but grew again in 1998 estimated 350,000, thus the asylum was the primary stream of European immigration, because of wars people from Bosnia, and Kosovo, people from Eastern Europe because of communist rule(Communist rule of Nicolae Ceausescu in Romania and his state owned abuse policy on Romanians) decided to immigrate or applied asylum to Western European countries for a better life and escape from the Eastern European communism, they were from ethnic communities of Bosnia and Kosovo to general citizens of Eastern European countries, countries like China, Afghanistan, Somalia, Sri Lanka, Yugoslavia, Poland are the top asylum seekers countries to the UK, thus the asylum issue turns into Pan-European issue then domestic, in Ireland in 1992 asylum application was estimated 1992 while in 1998 it was estimated 4,600, Germany received more refugees than other EU member countries, Austria, Holland, Sweden, Switzerland also received bigger asylum applications and refugees, while in Spain, Italy it was lower and in Britain it was middle, however the debate was raised by the nativist on its legality and for the security of their native citizens, Bonn Government took initiatives by the tightening of their liberal asylum policies to the context of Balkan influx in early 90's, Germanies Safe Third Country rule was a strict government initiative, under this rule Germany recognizes all of its neighbouring countries as safe country and therefore people were from those countries would not eligible for asylum seeking to Germany, Germanies rule Safe Third Country in 1993 brought the decline of asylum application to Germany and it went to other EU members countries, however in Holland asylum and refugee is now a big debate and issue, in Italy the question raises faster on how to stop illegal immigration, refugees or asylum application from Albania and as a result the leaders of antiimmigration, nativism, nationalism are getting success in Italy, though in France and Spain asylum is not an big issue but the government starts taking actions to deport illegal immigrants, takes strict actions on those hunger strikers who supports illegality on the bases of humanitarian way, thus in EU, debate, discussion starts to stop and reduce any form of immigration and provides more development aid, debt relief, and fair trade as other initiatives with strict option which is deportation and rejecting false asylum application, however economic immigration is continuing in Europe because of the skilled based immigrants, the native population in Europe declines like Italy will lose 28 percent of its population by 2015 and it needs to start import 3,50,000 skilled immigrants every year, Europe and America are taking steps to attract more economic migrants from around the world and to choose highly skilled people to invite as immigrants in Europe and America for their economic boost and population increasement because of decreased native population, Congress of the United States approves estimated 2,00000 skilled workers visas, while Germany wants 20,000 software engineers particularly from India, Britain wants to recruit East European computer experts, however the problem of illegal immigration is growing because of small wars, natural disaster world-wide, however EU, Britain took initiatives to reduce the culture of illegality and invites immigrants through selective primary immigration category such as skilled workers program. Problems including mental health is worse among immigrants and refugees world-wide, it is because of their undocumented status, anxiousness of arresting by police at any time due to illegal status, low income, no job situation, cultural shock, loneliness, depression make them violent sometime, and as a result they commit suicide or go for illegal activities, 
refugees are at higher risk than the general population for a varieties of psychiatric disorders related to their war, violence, torture, forced migration, exile etc. First Generation of migrant's people from developing countries are affected by schizophrenia (estimated 2.7 percent) and it is wider than the Second Generation such as their children, it is somehow affected by discrimination and racism because of their black skin colour, migrants from Caribbean to the USA especially men are affected by mental disorder while women are not affected, racism and discrimination have been found in Canadian immigrants society as well but it is not that open and wider than the USA and thus mental illness comes and affects immigrants societies, migration has three forms which is changes in personal ties and reconstruction of social network, moving from one socio-economic structure to another, and the shift from one cultural ideas to another, not only that migration itself has three phases that is pre-migration, migration and the post migration and each stages have various risks, such as during pre-migration there is disruptions to usual social rules and networking, during migration, immigrants go through longer uncertainty about their approval of immigration and situations exposes them to be violent, refugees goes through the worst moments due to the extension of their living in camps with poor resources and violence among them, in some countries asylum seekers keeps in a detention centre with terrible condition such as violent abuse with them by the authority which creates a sense of powerlessness and thus can provoke depression or other mental health problems, however when resettlement is successful and optimism comes as dream, immigrants feels like their honeymoon, unfortunately this honeymoon does not stays longer because of their failure for good resettlement by good job, good financial base and it is because of inequality, discrimination of advanced societies, language barriers, educational barriers, social isolation, denial of their academic credentials from their country education, or even it is accepted by the government but employer in the real market does not recognize in most cases, it creates post-traumatic disorder and exposes violence later, change of culture is also an exposure to violence due to identity and family life challenges, migrants youths are at high risk for psychopathologic disorder, posttraumatic stress disorder, depression, problems from abuse, however the rate of psychiatric disorder is not that high than the native-born children in Canada, psychiatric disorder is increasing among young refuges world-wide including Canada, refugees children and youth mostly faces social and academic disconnection during their preimmigration period and affects their socio-academic development because of disconnection or to accept a completely new socio-academics-cultural entity, lack of knowledge, unwillingness to get help or to take medical treatment, barriers, unwillingness to get help for postpartum depression are few disorder for women migrants, rape and other sexual abuse are few dangerous issues makes women mentally disorder, their maternal illness may be turn into mental illness due to shame and loss their child, seniors are small part of the refugees and immigrants, female sex, less education, unemployment, poor health, heart diseases, diabetic, asthma, divorced, lack of social support and isolation are dangerous issues makes them mentally ill, therefore as a treatment attention must be given to different contextual and influential issues which helps to create mental illness among migrants and refugees, intercultural communication, adaptation, social integration need to be more effective to accept those migrants people, keeping interpreters for their understanding because of language barriers in broad way, professional interpreters can improve communication between the patients and physician, they can increase the disclosure of psychological symptoms among immigrants and refugee communities, interpreter or other communicator can be an advocate or cultural broker for those immigrants and refugees, such as Dr. Austin Albert Mardon, who is a prominent 
advocate of mental illness and a helper of those people at the City of Edmonton, Alberta, Canada, working with family need to be more secret for their confidentiality, trusting and respecting their cultural values as they are from various cultural and religious backgrounds and thus to build a therapeutic alliances, empowerment between advocate or cultural broker or communicator and physician with family who have mental disorder, community organization particularly in urban centre need to be more flexible divided by multiethnic organizations who supports for settlement and integration and group specific to various ethnic background organizations who provides a sense of amalgamation, togetherness with the main stream, Edmonton Multicultural Women Education, IndoCanada Women Association in Edmonton, Canadian Civil Society(CCS) or BECA, University of Alberta's various mental health organizations are organizations in urban centre of the city that provides lectures, workshop, symposium, supports on mental health for the refugees and immigrants communities and help those people to participate by financial sponsorship and thus are trying to their best to letting them understand about facilities in a new societies for their best efforts and for their developments on socially, mentally, economically, academically, culturally. It is true that polarisation, radicalisation, racism, nationalism, political conflicts, favouritism are increasing in Americas and Europe and therefore problem is increasing as well for the integration of immigrants and refugees, it is showing also on legal economic immigrants as well, due to crisis from three main countries like Syria, Afghanistan and Iraq, West are facing economic problem due to torn of illegal immigration and refugee claiming and the amount is out of control, refugees are acting as real and fictional characters which is good enough for confusion about the problem, in 2015 Europe received estimated 1.3 million refugees, about 0.2 percent of the entire population of Europe, Germany is the worst victim country estimated 8,00000 refugees in 2015, as a result this problems creates several other social and political problem such as the rises of anti-Islamism sentiments, nationalist and racist movement in Europe and US and thus issue of refugees is now a vital political player in politics world-wide which is not good but bad for everywhere just like a cancer, according to PEW Research Centre, majority people of every European countries believe that refugees are their threat, refugees are problem to create terrorism and it has created and spread over Europe, France, Belgium, Germany are great example of terrorists incidents, according to Danish newspaper Søndagsavisen, Denmark is not thinking on climate change or pollution but deeply thinking on its immigrants, the feeling of them and us is really dangerous, thinking on those strangers who comes and creates economic and identity crisis in Europe and US are various example of increasing fundamentalism among native Americans and European and it is not good, in the future illegal immigration and refugee claiming will increase due to unstoppable war in Syria, Iraq, Afghanistan, civil war in Libya, North Africa and thus problems for Europe and America will increase as well to manage those refugees and illegal immigrants into their country and to integrate into their society, so no doubt that the issue of refugees and immigrants is going to be the biggest problem on the planet, however Europe needs refugees and immigrants for the fulfilment of their lacking man power and because of small young generation with improved education and employment opportunities. The United States history of immigration was boosted by the Immigration Act amendments of 1965, USA declared an equal footing among Ethiopian, the Turk, German, and the Englishman, because of few amendments, immigrants from Latin America are coming to the US larger than South and Central America due to their faster population growth, unemployment problem, demands of youth than the Central and South, immigration history said that from 1930-1960 estimated 80 percent of America's immigrants came from Europe and Canada, from 1977-79 it was around 40 
percent each from Asia and Latin America, during the decade top ten countries were Mexico, Philippines, Korea, China, Taiwan, Vietnam, India, Jamaica, Dominican Republic, Cuba and the UK. Relatives of the citizens of the USA came largely because of sponsorship, it was estimated 1,50000, in 1980 estimated 125,000 Cubans and Haitians immigrated to USA's Southern Florida as an especial entrants, since 1975 US accepted estimated half a million refugees from Indochina, more than 160,000 came in 1980 alone which together with Cuban's and Haitians was estimated 808,000 legal immigrants, it was not good for the US and various political leaders expressed their tension on this foreign flow, According to the census 1980 Asian immigrants was the fastest growing ethnic group in the United States and their flow from all over Asia is increasing every year both legally and illegally beside a hope that US is the land for new hope and dream, influence of Asian culture, music, teaching style, languages, contribution through entrepreneurship, education, business have increased in US society as an empowered newly social model, but there was a history of sorrow and grief among immigrants in the past, it was terrible discrimination of equality, no proper jobs, no rights, immigrants from China came to the US during $19^{\text {th }}$ century as the provider of US cheap labor force and for the construction of Western railroads, it was the sorrow of insufficient money, language barrier, dying trying to build the railroads, however yet a group became merchants and helped to grow the business between China and US at the beginning of 19 centuries, Japanese and Koreans came to West Coast mostly to work as a farm laborers, however Pearl harbour incidents imprisoned Japanese due to sentiment against oriental intensified, however immigrants from Korea, Japan, Taiwan always increases than decreases and due to South Vietnam fell US government accepted thousands of refugees from Southeast Asia, estimated 50,000 Vietnamese, Laotians, Cambodians have settled in the county and have two million people, Orange countries Asians represents more than one tenth of the total numbers of Asian refugees, Orange country of the US is flooded by Asian immigrants and it can be seen by countries public school, medical care, Dong Loi a successful businessman with several stores in Vietnam came to the US in 1975 with his entire family, in the US he owned a fish market in the orange country and his brothers are working in a fish market to help him and to grow their fishing business and living together a total of 10 family members in a rented two bedrooms house, though sometime they are getting threat from phone call from Vietnamese gang due to their flourishing business but ultimately they are happy in the USA, at least they are free, foods are not only chow Mein or Cantonese soup, there are several oriental foods are available in the entire United States, estimated 269 Japanese restaurants are only in New York, thus Asian immigrants spread between Boston to Seattle(east to west of the Unite States), they are receiving blocks like parts of the lower east side in New York and the fringes of the North Beach section of San Francisco, estimated 10,000 Korean communities lives at Olympic boulevard of Los Angeles city, on the north side of Chicago Koreans, Japanese and Thai merchants turns a part of clerks street into a lively inviting oriental enclave etc. In 1981 659,000 immigrants and refugees legally entered the US and estimated 5,00000 or more illegally entered, estimated 70 percent of the total immigrants settled in California, Florida, New Jersey, New York, Texas and Illinois and centred them in urban areas of those cities and states, some of them established their business in black communities, some of them compete for job with black communities of those states, estimated 70 percent of total immigrants goes to technical field for their job perspective. Asian immigration is more soft and technical way than the Mexican wave, history of Mexican immigration to the States was not that good, in 1981 estimated 83,811 undocumented aliens were caught along the border, smugglers are charging $\$ 12,00$ per person to ride any US cities from the US-Mexico border illegally, as a 
result it was tremendous pressure for the US government to provide jobs to the US citizens because of unemployment problems and illegal immigration from Mexico is one of the severe problem, this problem has seen also in India as well, surrounding poor and small Indian neighbouring countries people are entering in India illegally because of the land border advantage and Indian citizens are getting job because of over population and undocumented immigrants people, those undocumented people are doing anything by cash and thus making money, sending money to their countries and becoming rich through India, similarly it has seen in US-Mexico border, Rio-Grande, El-Paso, thousands of Mexican undocumented children enrolled in school in Chicago and New York and thus turned those cities as bilingual city, New York and Chicago both have bilingual program in the school for children illegally in the country, however those undocumented aliens are doing any kind of jobs that actually does not want by American citizens but due to unemployment problem, Americans wish to do any kinds of jobs but they are not getting because of those Mexicans, as per border patrols, it cannot do anything to control illegal immigrants from Mexico unless Congress brings tough sanctions against employers who hires illegals because of less payment lower than the minimum wages. Refugees are those who came for shelter due to horrific situation in their countries and or forcedly leave but once they are in, they never return and at the end turned into immigrants, refugee status always gets especial consideration through international law and national immigration policy, but then a problem is who is legitimate refugee and who is immigrants? What about Haitians refugees status in the US, because of confusion of their countries situation, their status in their country, they are international embarrassment to the United States, therefore prevention and freely return are few ways that can reduce refugees by making them self-sufficient, US provided assistance in Horn of Africa through its various voluntary organizations under the umbrella of UNCHR, supports various health and education projects for African refugees who are in various countries in Africa from their own land, US is the leading contributor to the ICRC program that aids refugees in areas of armed conflicts and civil strife, US provided one third of the assistance program for the assistance of Salvadorian, Guatemalans, Nicaraguans who have taken refuge in Honduras and other countries in the area, US provided assistance and aid through UNCHR for estimated 2.9 million Afghans refugees to Pakistan, continues to provide financial support to the UN Relief and Works Agency(UNRWA) which is responsible for assuring basic life support to Palestine refugees in the Near East, US provided estimated \$100 million for the assistance of Lebanese and Palestinian refugees during the invasion of Lebanon in 1982, the UN border relief operation continues to coordinate relief program on the ThaiKampuchean border for the assistance of Khmer communities from Kampuchea to Thailand because of Vietnams invasion, re-settlement internationally other than their own region also increased, therefore USA provided few number for each region of the world for refugee acceptance to the US, such as(1984) for Africa it was estimated 3000, for East Asia it was estimated 50,000, for Eastern Europe and the USSR it was for 12000, for Latin America and Caribbean it was for 1000, for East and South Asia it was for 6000, total 72000 refugees would allowed to take by the USA in 1984, the problem of re-settlement of refugees is yet a big and worst problem on the globe, as per statistics there are estimated $7,816,200$ refugees in 60 countries, if they are equally divided among countries then it will not so bad but it is bad because of unequal distribution such as Pakistan has 2,800000 Afghan refugees where Nigeria has only estimated 400, USA is the largest number refugees accepted country from the beginning, estimated 1,003,000 refugees had been accepted, USA is the largest financial contributor country as well, provide finances to international refugees aid agencies, but is it possible by USA to provide financial aid, 
contribution to entire world and thus solve the world's most worst problem? No every country must join with the USA and help for solution, USA is a super power but status cannot solve this worst issue currently, therefore an universal help and efforts are required, in the developing world there are over 3.5 billion people estimated or more, in 2025 population of Panama, Costa Rica, El Salvador, Guatemala, Nicaragua, Honduras, in total will be estimated 70 million, they are all potential migrants to the USA over the centuries and will become labor force of the developing countries with an explosive power far beyond anything than before, the massive impact of immigration can have on the ultimate size of the United States population can be seen when projected out of the year 2080, it would 250 million, the negative side is to include illegal immigrants in the national census which is the indirect acceptance of those undocumented aliens as a political tool for the advancements of certain interest by the political leaders, illegal immigration is good for US dirty works but what happens when those undocumented workers will try for a better job by approaching employers?

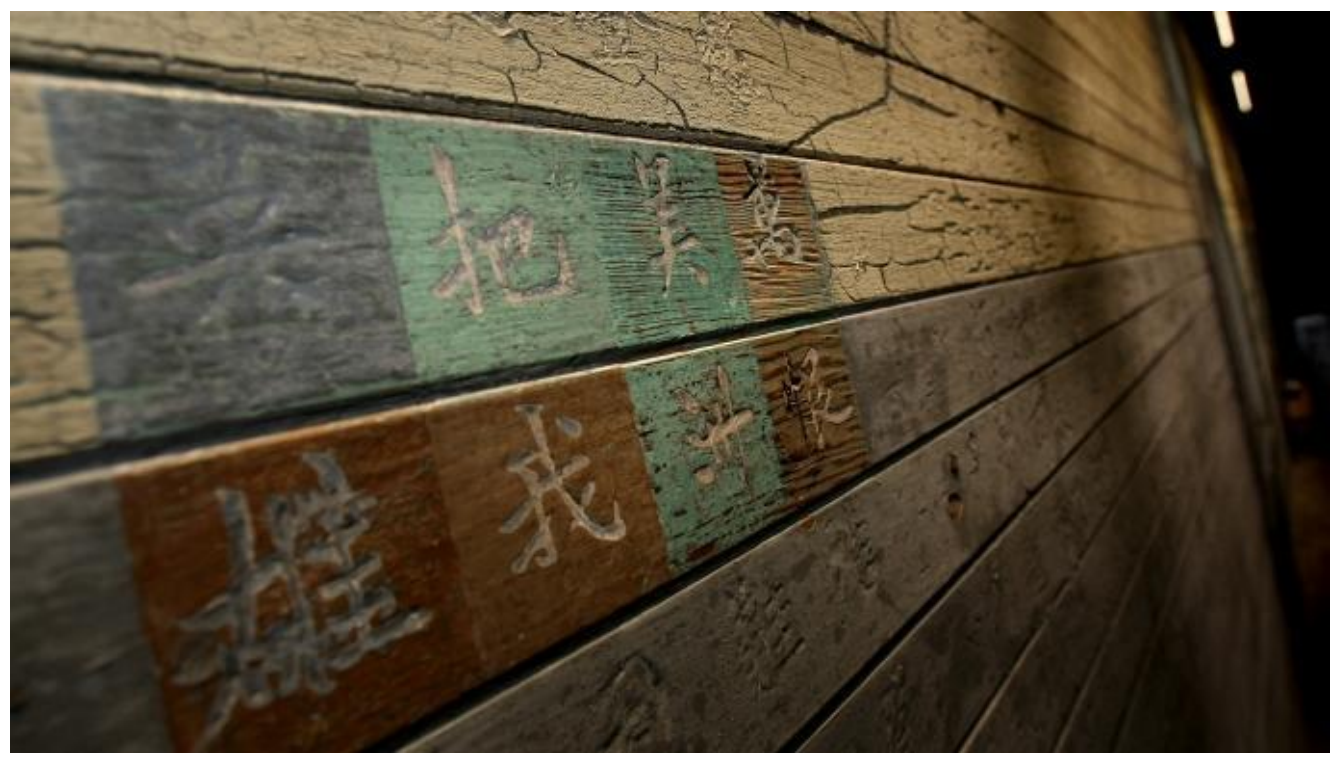

Historical Immigration and Image

In Chicago wages of illegal immigrants were found estimated $\$ 9000$ a year, in Denver it was over $\$ 13000$ working in electronics, meat-packing plants, rubber products, manufacturing, candy products etc. one third of all workers in commercial construction in Houston found to be illegally employed earning from $\$ 4.00$ to $\$ 9.50$ and estimated $\$ 20,000$ a year, the problem is it is illegal to work in the United States without paper but it is not illegal to hire those people by the US employers for their production, therefore to protect US national interest the relations between North and South need to be revised, in developing world population is increasing, Latin, Central, South America's populations are the future immigrants to the US no doubt, war, poverty is increasing in developing countries and thus chances of refugee claiming is increasing as well, the United States, Canada, Australia and Western Europe need to be focused on their immigration policies, establishment of a forced border, enforceable immigration statutes, more international concern from them to all third world countries and the modification of refugee policies, otherwise those countries would be the victims of increasing population of third world 
countries and it is a good way for those developing countries to reduce pressure of over population by migration whether legally or illegally, finally few things such as flood of Mexican's illegal immigration, abuse of government welfare by the illegal immigrants, high volume of illegal immigration, problem of native unemployment, uneducated and unskilled illegal immigrants are not good for USA in the long run, it is increasing yearly, if they are careless to make enforced immigration law, careless about internationally concern with developing countries on their population control, then one day USA will fall in deep problem and there will be no solution in that time.

\section{CONCLUSION}

As per American sociologist-demographer Kingsley Davis, fastest population is growing in the poorest region, the slowest growth in the richest, in 1940, 65 percent of the people on the earth lived in developing countries, today it is estimated 80 percent of some 6.1 billion people, the result is movement around the world from Mexico to Central America, United States, from Guinea to Ivory-Coast, Colombia to Venezuela, the rapid growth of industrialization in OPEC countries such as Kuwait and the UAE, 70 to 80 percent of their population are immigrants, temporary residents, illegal immigrants from countries like Ghana and Colombia have moved to Venezuela and Nigeria, recently caught Ghanaians from Nigeria uncovered the story of illegal immigrants, estimated 25 percentage of people in Ivory Coast are foreigners, they are competing for limited jobs and land with natives, the result id economic bubble bursts, in 1969 Ghana expulsed estimated 2,00000 illegal persons who had no residence permit in Ghana mostly Nigerians, in Assam, India Bangladeshi had been massacred, are those examples of solutions to stop or reduce illegal immigrants when it blows up in the name of competition with native inhabitants, Western Europe is taking initiatives, USA is talking with Amnesty International but is it reducing? The Universal Declaration of Human Rights adopted by the United Nations General Assembly in 1948 states that everyone has the right to leave any country including his own and to that return country, but it has not been honoured by developing countries, they cannot because of growing population, globalization is dynamic and flexible for new world order, it is good for developing world to connect with developed world and link trade, cultural exchanges, academic exchanges, and for the innovation of technology, it makes the world without border but globalization also creates problem in the name of illegal immigrants world-wide, illegal immigrants are not the part of economic immigrants and refugees on humanitarian claims, illegal immigrants are undocumented and to taking advantages of open border, though borders are not open it has several processes like emergence of nation-state, barriers from pressure groups for immigration but it is not enough to stop illegal immigration and border patrol cannot do anything until a tough decision made by political leaders and it has to be universal, the problem is for developed world, they are concerned about problems of illegal immigrants, problem of population growth in developing countries, but unfortunately third world countries are not taking initiatives over birth control because of their mindset in the name of capital human resources, they think population is their asset, the problem is, a big percentage of their growing population is the potential immigrants of developed countries for their better life and this is a real problem for the developed countries because of job management, accommodation management and the management of law and order, they are setup in different ways and immigrants cannot match their rules and regulations, and if undocumented then it is very difficult to setup in a civil society, problem thus creates, then turn into conflict and finally racial incidents, it is finally called terrorism, growing 
population in developing countries are problems of various ways not only in their countries but for the world wide, it linked with poverty, lack of food and water, improper education, uncertainty, lack of sustained environment and finally terrorism creates from those issues when people are helpless economically, after all money is important for life world-wide and when money does not show up, people can do anything for livelihood, it can be illegal immigration to better countries, it can be terrorism anywhere, these are all due to globalization, so the question is how does problem like illegal immigration can be reduced? The answer is through globalization, it can be sources for the concerning of this problems and to take steps through cooperation, connection between developed countries and developing countries, developed countries can lead those issues and developing countries must listen their advice what to do to stop population growth, Canada and the USA have several assistance program for refugees, they have taken initiatives for those undocumented people and rest of the world has to be cooperative with them by linking, connecting and confirming and forgetting clashes, divisions etc. an united hand made by every country can stop illegal immigration, war, violence that is made by human, globalization reduces the strictness of countries boundary or border but yet no nation has open door policy, then how does the problem of undocumented immigration is growing yearly? A through discussion of alternative solutions world-wide has to be discovered for the reduction of the problem of refugees and immigration world-wide.

\section{REFERENCES}

2017 Annual report to parliament on immigration Canada. Retrieved from https://www.canada.ca/en/immigration-refugees-citizenship/corporate/publicationsmanuals/annual-report-parliament-immigration-2017.html

Fuller, E. (2014, August 6). Illegal vs. legal immigration is a global issue. Forbes. Retrieve From https://www.forbes.com/sites/edfuller/2014/08/06/illegal-vs-legal-immigration-is-a-globalissue/

Global issues- natural resources Canada. Implications for international migration to Canada. Retrieve from https://www.nrcan.gc.ca/environment/resources/publications/impactsadaptation/reports/assessments/2008/ch9/10407

H. Kigge. Addressing the challenges of refugees and immigrants. (2017, February 27). Retrieve from https://webcache.googleusercontent.com/search?q=cache:jeG9Z0cRWQ0J

Hall, B. Immigration in the European Union: problem or solution. Centre for European reform. London. $\quad$ Retrieved from http://oecdobserver.org/news/archivestory.php/aid/337/Immigration_in_the_European_Uni on:_problem_or_solution_.html

Immigration- Global Issues. Retrieved from http://www.globalissues.org/article/537/immigration

Johnson, K. \& Kane, T. The real problem with immigration and the real solution. (2006, march 1). Retrieved from https://www.heritage.org/immigration/.../the-real-problem-immigration-andthe-real-solution

Kirmayer, LJ. Mental health problems in immigrants and refugees: general approach in primary care. CMAJ. (2011, September 6). Retrieved from www.cmaj.ca/content/cmaj/183/12/E959.full.pdf

Little. B, The Birth of Illegal Immigration. (2017. September 07). Retrieved from http:/ / www.history.com/news/the-birth-of-illegal-immigration

Mckenna, C. \& Hoban, B. (2017, December 18). Problems and solutions to the international migrant crisis. Retrieve from https://www.brookings.edu/blog/brookingsnow /2017/12/18/problems-and-solutions-to-the-international-migrant-crisis / 
Steven, A. The problem of immigration. 1. 57. New York: The H.W. Wilson Company, 1985. Print.

Top ten migration issues of 2017. (2017, December20). Retrieved from https://www.migrationpolicy.org/programs/migration-information-source/top-10-migrationissues-2017

World refugee problem. B, Sahid, J. (2016, September 25). The Express Tribune. Retrieved from https://tribune.com.pk/story/1188183/world-refugee-problem/

$$
--0--
$$

Publish Online and Print Version Both

Online ISSN: 2312-2021

Google Scholar: https://goo.gl/eozEWi 